\title{
Managing to reinvent strong publicness in a privatized world
}

Fabrice HAMELIN ${ }^{1}$ and Vincent SPENLEHAUER ${ }^{2}$

"Everything changes so that nothing changes'

G. Tomasi di Lampedusa, The Leopard

\begin{abstract}
:
How can a specialized public organization, of which the operational sector has brutally fragmented and privatized, maintain its unity and publicness? The paper looks at how the British Transport Police (BTP) has adapted to the fragmentation and privatization of British Rail since 1993. The fact that the BTP has remained public and national is all the more surprising since a return to the pre-WWII configuration, with each Train Operating Company (TOC) having and running its own police, could be technically envisaged. The answer to the initial question is quite simple. The police organization under examination has intelligently reinvented its publicness, with the help and/or the harshly negotiated assent of its referring political and economic authorities.
\end{abstract}

\section{Introduction}

How can a specialized public organization, of which the operational sector has been brutally and totally fragmented and privatized, maintain its publicness and also its unity? This paper will address the question through a case study of the British Transport Police (BTP), the public organization in charge of policing the British railway system. The research was conducted twelve years after the fragmentation and privatization of British Rail in 1993. Empirically, the question is how the British Transport Police (BTP), despite the fragmentation and privatization of British Rail, has remained public, national and united.

\footnotetext{
${ }^{1}$ Researcher at the French institute of sciences and technology for transport, development and networks (Université Paris Est - IFSTTAR) (fabrice.hamelin@ifsttar.fr).

${ }^{2}$ Researcher at the LATTS (CNRS-Université Paris-Est-ENPC), director of the public policy department of the Ecole Nationale des Ponts et Chaussées - ParisTech (corresponding author: vincent.spenlehauer@enpc.fr)
} 
The answer to this question is quite simple. During the decade following the major turning point of 1993, the police organization under examination has reinvented its publicness, with the help and the assent of both its referring external political authorities, the British Department for Transport, the Home Office, and local authorities, and also of its external economic authorities, the twenty or so "train operating companies" (TOCs), and a new Transport Authority. However, as simple as the answer is, it proceeds from the cross-fertilization of two analytical approaches which both question the classical public/private dichotomy and are complexity-compatible.

The first approach, advised by Michael Barzelay (2001; Barzelay and Gallego 2006), is one of common sense. It consists in focusing the study of public management policy reforms not so much on their cognitive, ideological or doctrinaire aspects but more on their implementation within policy domains of which the specificity must always be kept in mind. Of course, this approach necessitates a substantial fieldwork effort, aimed at collecting first-hand data. The second approach, called dimensional publicness theory, is based on the assumption that the notion of publicness is regionally and historically contingent (Pesch 2005). It shows at least three crucial dimensions to be explored, political authority, economic authority, and organizational adhesion to public values (Bozeman and Bretschneider 1994; Bozeman 2009), and cannot in any case be reducible to the criterion of legal public ownership. In other terms, our research suggests that public policy research and organizational studies needs to develop a joint pragmatic semantic network which can account for the unavoidable multi-institutional and hybrid structure of every policy domain (Moulton 2009), police included.

Over the more than ten years since 1993, the British Transport Police (BTP) has seen its two relevant policy environments, rail transportation and security governances, undergo profound changes (Appleby 1995). The Railways Act of 1993 was intended to transfer the rail infrastructure to a single private manager, Railtrack, while allowing for allocation of freight and passenger transport to different "Train or Freight Operating Companies" (TOCs or FOCs). 
Between 1994 and 1997 John Major's British government implemented a total, "line by line" privatization of British Rail. And after 1997, New Labour under Tony Blair did not do much to challenge this reform (Lodge 2002). The personnel downsizing caused by the reform of the UK rail sector was quite impressive: 128,000 employees in 1993, 51,000 in 2001 (Goujon 2004). However, the total privatization and fragmentation of British Rail did not bring with it the privatization and fragmentation of the British Transport Police (BTP). Having today more than 4,500 agents, two thirds of whom are sworn officers, the BTP is a non-Home Office police force (its relevant authority is the Department for Transport). Historically, the BTP is the outcome of the unification and nationalization, in the aftermath of World War II, of all the private railway police forces, including those in charge of the undergrounds in London, Birmingham and Liverpool. Surprisingly the Railways Act of 1993 makes no explicit mention of the BTP at all. It was only a year later that there came a rider, the "Transport Police (Jurisdiction) Act" of 24 March 1994, something very much out of the ordinary in British legislative history, stipulating obligatory "agreements" between the private rail operators and the BTP (Gourvish, Anson 2002, p. 422). Today, the BTP is the national police force for the railways, providing a policing service to Network Rail, rail and rail freight operating companies, their staff and their passengers throughout England, Wales and Scotland. BTP is also responsible for policing the London Underground System, the Docklands Light Railway, the Midland Metro Tram System and Croydon Tramlink (AECOM 2011).

Over the same period, security governance has also undergone marked changes in England (Johnston 1992; Jones and Newburn 2002). The general literature dealing with the police and security governance looks into changes in institutional, organizational and professional configurations over the last twenty years (Ericson and Haggerty 1997; Bailey and Shearing 2001; Johnston and Shearing 2003), along with questions about the classical public/private dichotomy, by emphasizing the close and complex overlap between the two worlds (Dupont 2006 ; Ferret and Spenlehauer 2009). This semantic network identifies, in policing systems, three main factors 
of evolution which are highly applicable to the sector under study: the advent of new public management (Hood 1991; Jones and Newburn 2002, p. 137), the expansion of the private security industry (Grabosky 2007) with the concomitant pluralization of policing (Bailey and Shearing 1996), and the appearance of new forms of social control (Jones and Newburn 2002, pp. 139-142). Concerning 'user-pays' policing, by permanent arrangement, around 95 per cent of the BTP budget is provided by the rail industry (TOCs, FOCs, Network Rail and London Underground), with the rest supplied by government grants (Ayling and Shearing 2008, p. 33). Concerning the "police extended family" trend (Johnston 2003), since 2005, the proportion of civil employees and PCSOs has continued to increase at a rate of around $10 \%$ per year, while the number of police officers in BTP staff has increased by only 1\% (AECOM 2011, p. 6).

The main intellectual step to take in order to understand how the BTP coped with these two major environmental changes and ultimately remained united and public is to consider the usual public/private dichotomy as what it is: an intellectual caricature of reality. The rail system and its dedicated police apparatus are both hybrids from an organizational and a professional point of view. They thus show considerable convergence and can find a fit with each other, finally reaching fairly stable compromises. What must also be emphasized are the opportunities offered to the BTP. Both the "new public management" design of rail security governance and certain specific circumstantial social phenomena such as transport hooliganism and terrorism have helped the BTP preserve a status at once public and national even when confronted with partners no longer necessarily in favor of this on principle. In other words, the BTP and the relatively cohesive and motivated corps of officers it relies upon have not behaved like a besieged citadel desperately attempting to fight off broad public policy changes. Over the last twenty years, behind an unchanged institutional façade, the BTP has transformed itself with, and not against, the system of actors and institutions in charge of the railway system operations and its security. This system has welcomed new partners and has modified both its practices and its representations of security issues. This profound adaptation on the part of the BTP has enabled it 
to remain the central actor in the now very plural system of rail security and safety governance in the United Kingdom. This case study thus provides an understanding of a hitherto unknown aspect of the British state. The reconfiguration of the organic state, mainly caused in this instance by privatization of the rail sector, is not a sign of weakening or of submission to the conquering logic of the free and competitive market. Nor does maintaining a policing activity, hybrid but still supervised by a public police organization, reflect a forced or strategic fallback by a state reduced solely to exercising its governing functions. Our intention via the example of the BTP is to demonstrate how, on the contrary, a public and "professional bureaucracy" (Mintzberg 1979) can succeed in adapting to sudden change so as to preserve, and even, extend its powers among the increasingly numerous co-governors of rail safety as well as its public professional identity aimed at serving all its publics: mere citizens, users and TOCs.

The following table illustrates the research design and methodology used:

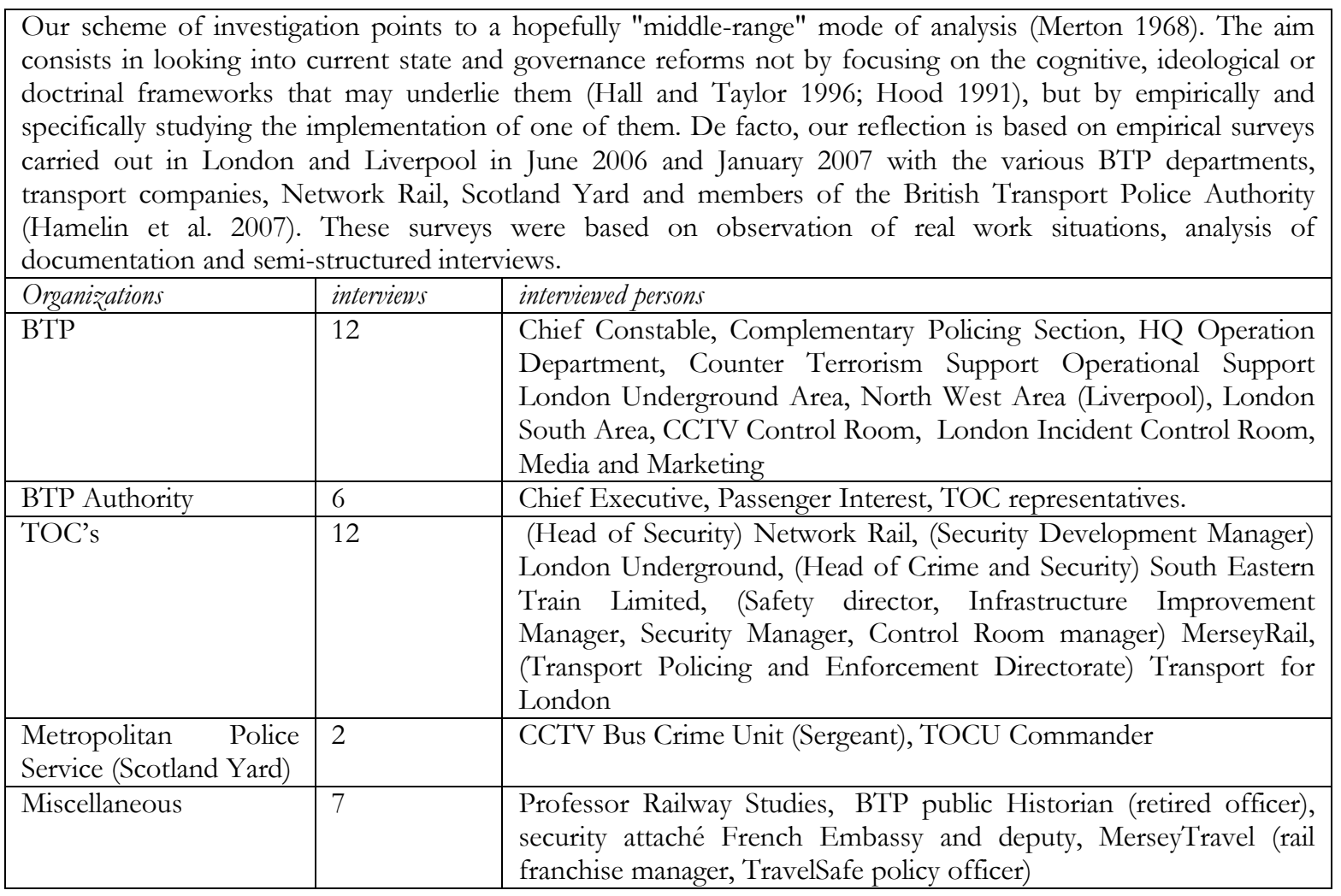




\section{“Public, Private, neither, both": the setting up of a hybrid system (Anderson 2012)}

The public/private polarity is irrelevant to an understanding of the rail system and its security. As a consequence the discrepancy between the rail transport system and that of the actors in charge of its security is not as clear-cut as it seems at first glance. In both cases we have de facto hybrid systems (Johnston 1992), and marked convergences bring the two together. The public transport sector, for instance, provides an illustration of the absence of an institutional police monopoly in the public security field. This means the public/private debate can be looked at not simply in terms of rivalry, but rather as part of a broader spectrum of considerations extending from competition to subcontracting and from cooperation to passive non-cooperation or avoidance (Zhong and Grabosky, 2009, p. 437), as well as involving logics of duplication, division of labor, "vassalization" and co-ordination. As advised by Barry Bozeman (1987), it is judicious to apprehend all organizations as being influenced by both external political authority and external economic authority. Political authority describes the degree to which the BTP is subject to government control, and economic authority the degree to which this organization is being funded. What is essential here is to gauge the particular mix of political and economic authority influencing BTP's organization and behavior in security implementation.

\section{The complexity and the pretenses of BTP external economic authorities}

The 1994 «Transport Police (Jurisdiction) Act" gave the TOCs (among them the infrastructure manager Railtrack) complete economic authority over the BTP, and this was very consistent with the spirit of the 1993 Railways Act. In effect, the political argument put forward by John Major's government in favor of the Railways Act reflected neoliberal reasoning: the taxpayer should cease to keep afloat a very mediocre rail service whose share of the market was inexorably being eroded year after year by road and, to a lesser extent, air transport. According to the Tory credo of the time, entrusting the ownership, management and maintenance of the rail network to private 
enterprise would move the system from a "taxpayer and user pay" rationale to an "only the user pays" one, with no built-in financial burden for the taxpayer.

However, in practice, the financial disengagement of the British state was never achieved. To attract firms into the new market, the British government asked that tenders for franchises be accompanied by a "business plan" specifying the number of years during which they would receive a public subsidy, and after which they would not only cease to be subsidized but would also pay the state a fee which would eventually make privatization of the sector profitable for the taxpayer (Goujon 2004, p. 1; interviews). Even in the Conservative camp there were grave doubts as to the realism of this optimistic approach. In fact, from 1967 to 1987 annual investment in the rail industry was low. Then, from 1987 (1 £billion) to 1993 ( 2 fbillion), investment increased rather significantly both for infrastructure and rolling stock but had no effect at all on the decline in rail traffic. In 1993, rail's share of overall passenger travel fell to less than 4\% (GB Transport statistics bulletin 2002; for information, investment in 2002 was about $4.2 f$ billion). However, these doubts did not hamper the ongoing process, for the implicit goal for the majority of members of Parliament was to build up a "political quiescence" strategy (Edelman 1964) ensuring that the British rail system went to its death slowly but surely (interviews with two well-informed people). It was thought that in comparison with the status quo the dismantling/privatization operation would clearly have a positive impact on public finances.

Moreover the implementation of public policy often plays strange tricks on its instigators (Pressmann and Wildavsky 1973; Thoenig and Dupuy 1979). In this case something unforeseen happened: by heavily subsidizing "in settlement" in the privatization of the rail system the British state did not "liquidate" it. On the contrary, it eventually revitalized, modernized and expanded it. In the period 1995-2004, the number of passengers rose by 40\%. By the time New Labour led by Tony Blair came to power in 1997, passenger transport by rail no longer appeared to be a doomed sector. Unsurprisingly, in recent years this reversal of the previous trend has been reinforced by rising concern about environmental issues in transport. The question is no longer 
whether or not the British rail system will one day function at zero cost to the taxpayer, but rather how the taxpayer might one day pay a little less for a service whose existence and strategic character are now beyond challenge.

Today the financial viability of private Train Operating Companies depends to a large extent, and structurally, on subsidies built into their franchise contracts, with the state injecting some 5 billion Euros into the system each year (GB Transport Statistics Bulletin 2007). While the legal status of the private TOCs is watertight in terms of everyday management, the fact of being massively subsidized public service concessionaires entails a dependency which gives the state, the Department for Transport and its powerful Strategic Rail Authority (Hood 1983), a major role in their strategic management.

Thus with regard to the traveler security that more particularly interests us here, the TOCs cannot, and in reality do not, behave as sole principals although they are the BTP's sole economic authorities from a mere accounting point of view. Before the Second World War each TOC had its own police force and was free to decide on security levels and strategies on its rail network. Today they must share BTP services using personnel distribution keys based on quantified criteria common to all TOCs. Moreover they must accept the state's view of trains, stations, tracks, etc., in spite of their being privately managed, as "normal" public spaces whose security must be covered by a public policing policy jointly developed by the Department for Transport, in charge of the BTP, and the Home Office, in charge of most police forces in Great Britain. To take one example: currently a number of TOCs consider that the daily crime and antisocial behavior statistics for their lines are satisfactory. So, with a view to saving money and increasing profit margins, they would like to spend less on the BTP, whose manpower is costly, and more on cheaper private security personnel, while working to generate an overall feeling of security: "We don't need policemen to reassure the elderly and make them come in the evening. To keep the 'ticketless' out of the network is one important thing to do for instance (interview with a TOC safety director). For the moment this remains no more than wishful thinking, given that other TOCs, and especially the 
state, do not share their point of view, because of, for example, the terrorist threat. Regarding the costly reinforcement of the BTP counter-terrorism capacities the security manager of one important TOC told us: "Is it a justified effort or just a pretext for more BTP staff? But, ok, we pay, we are good citizens."

Obviously the case of the rail infrastructure manager should be distinguished from that of the TOCs. On 1 April 1994 the infrastructure was transferred to a single independent company - Railtrack - which was not actually privatised until 1996 (Freeman, Shaw 2000, pp. 34-35). From that date onwards, Britain's rail infrastructure was part of a private monopoly. Railtrack rapidly found itself facing two kinds of problems: a succession of serious accidents and major financial difficulties that raised the issue of the safety of the infrastructure and the signaling system. In September 1997, for instance, seven people were killed in Southall, west of London, when a passenger train failed to stop for a red light and collided with a freight train. In October 1999 two trains collided at Ladbroke Grove in West London. These incidents affected perceptions of the risk run by train passengers and gave rise to accusations, notably from the railway workers' unions, of insufficient Railtrack spending on network maintenance and repairs. Furthermore, at this time vandalism also became a very real threat (Freeman and Shaw 2000, p. 85). The upshot was that in October 2002 Railtrack was replaced by Network Rail, a state-owned and not-for-dividend company, with the massive hiring of 18,500 railway employees. Involved here were major changes which enhanced the UK's reputation as a laboratory for overt, extensive privatization of public services in the Western world. In other words, six years after privatization of the infrastructure, the state took back direct control of one of the vital components of the system, doing so basically in response to financial problems and the need to improve rail transport safety.

Finally, the specific case of the London Rail System's policing must be mentioned. The different components of the London rail system are London Underground, Docklands 
Light Railway and London Overground Rail Operations Limited. The BTP has the monopoly of policing this area but has also single customer: Transport for London. This is not a private company but a local government body created in 2000 as part of the Greater London Authority. TfL is controlled by a board whose members are appointed by the Mayor of London, who also chairs the Board (Ken Livingstone first, until the election of Boris Johnson as Mayor in 2008). TfL pays for BTP costs directly attributed to the policing of the London area railway system. This equals to about $25 \%$ of BTP's overall budget. But TfL has another transport security provider. Since 2002, the Metropolitan Police (MPS) has had a special unit, the Transport Operational Command Unit (TOCU), which is responsible for policing the surface routes, buses, roads and taxis, and is also funded by TfL. The sharing of responsibility with the BTP, in charge of the Underground and the railway system, is thus clear but quite fragile.

To sum up, then, privatization of passenger transport by rail is not without its ambiguities, given that the external economic authority over the BTP is exerted by:

- twenty or so private TOCs which are nevertheless very dependent on state subsidies and which must share BTP services with the other TOCs operating in the same BTP division ${ }^{3}$ (in other words, none of them are in a direct client/provider relationship with the BTP);

- one large, special TOC, Network Rail, which became state-owned and then "organically" public in 2002 ;

- last but not least, another large, indirect TOC, Transport for London, which is not stateowned, but nevertheless shows a very public status.

These ambiguities globally reduce the abnormal or problematic character of the real discrepancy between the private status of most TOCs and the public status of the BTP. However one cannot

\footnotetext{
${ }^{3}$ BTP operations are organized in seven geographical divisions (Greater London, South London, North London, Wales \& Western, North Western, North Eastern and Scotland).
} 
ignore the governance difficulties experienced by the BTP in coping with such a complex and hybrid clientele.

The BTP's external political authorities as multilevel governance

Beyond the funding aspects of the BTP, the issue of its governance has been central and recurring since 1994 (AECOM 2011). Since 2004 the main political authority to which the BTP is accountable has been the BTP Authority (BTPA), a "Non-Departmental Public Body" bringing together representatives of the rail industry (TOCs, Network Rail, and TfL) and of the users. Logically the BTPA is sponsored by the Department for Transport (DfT) of which the Secretary of State reports to Parliament. The Secretary of State in charge of transport can also require inspections of this police force. S/he can also direct the Authority to take measures to remedy the deficiencies of the BTP or to submit an action plan. S/he can provide ad hoc central funding where the force is required to contribute to national initiatives or where there are wider public benefits. For instance, in 2004, the Secretary provided counter-terrorism vehicles and equipment. Although the BTP is a non-Home Office police, the BTP units are part of the national policing service managed by the Home Office, which has sole responsibility for law and order matters in England and Wales, and the Scottish Executive for Scotland. So, at the national level, we can find a plural set of external political authorities with unequal prerogatives in steering BTP activity. At the sub-national level, one must not forget that the BTP functions within the frameworks of seven territorial divisions, each of them containing several local authorities (counties or municipalities). In order to explore the question of the external political authority exerted on the BTP at the regional level, let us first continue our visit to the London scene.

The BTP has never been the only police organization handling safety on London public transport. At the time of the survey, TfL was financing over 2000 police officers and Police Community Support Officers (PCSOs), almost 800 for the BTP and more than 1300 for the 
Metropolitan Police Service (MPS ; commonly known as Scotland yard), to underpin police work explicitly dedicated to safety on London public transport networks.

Throughout the 2000's a harsh political debate about the future of the BTP has concentrated on the merging of its London unit with the MPS ${ }^{4}$. The issue is at once highly political and very narrow in scope, being of interest only to the operators, the police and the local authorities. As our TfL interlocutors reminded us, Londoners make no distinction between TOCU and BTP agents. For those in favor, such a merger would prevent the bearers of new risks like Islamic terrorism from taking advantage of the fragmentation of policing provision (Johnston 1992; Blair 2002). Over the last ten years, the possibility of the merger has been explored several times and ultimately rejected. This option was proposed in 2005 by the Metropolitan Police and discussed by the House of Commons Transport Selected Committee. The official review done on this occasion confirmed the status quo and the continuing role of the BTP as a national specialized police force for the railways. Each of the public transport security actors expected to see the debate flare up again with the approach of the 2012 Olympic Games. In the last review, in 2011, the main argument in favor of the status quo is that the merger would place the BTP (amputated of its London unit) under a certain "critical mass" threshold (AECOM 2011).

But, unsurprisingly, TfL took advantage of this debate hanging like a Damocles sword over BTP's head, to exert strong political authority over the BTP, undermining its national status. More precisely in 2005, TfL implemented within the BTP London Unit, as well as the TOCU, the CompStat ("computerized statistics") system, the method and quantified management software package for police performance first tested by the New York Police Department (Gill \& Mamode 2006). But in London CompStat is not simply a means of measuring and discussing the results obtained by police officers in their sector. It is also presented by TfL management as a tool for strategic and operational coordination of the work of the different security governance

\footnotetext{
${ }^{4}$ Of course the City of London Police is also concerned by this debate
} 
partners. For the Underground it is intended as a means of measuring, discussing and improving the necessary cooperation between TfL and BTP agents.

"While the CompStat process used by the BTP's L Area is modelled after the successful efforts implemented in a number of other cities, there are some crucial differences. Most important is that the policing "client", - Transport for London - fully participates in the meeting. In most other CompStats, only police are engaged in direct questioning of police staff. (...) In the CompStat session, the Group Station Managers from the Reassurance Group being reviewed are also present to add their perspective and ensure that police teams are adequately addressing the problems of the group. In future Compstat sessions, it is intended that local communities in which Underground and DLR stations are located will also participate to ensure that policing strategies reflect neighbourbood concerns (...)" [Excerpt from the booklet accompanying the DVD Reassurance Policing and Compstat: The London Underground Experience, made by TfL in 2006].

The Compstat system is above all a supervisory tool for Tfl within the context of the Reassurance Policing Model strategy, which the London Transport organizing authority has adopted, and whose main priority is combating low-level offences like vandalism, fighting and antisocial behavior. These offences contribute markedly to feelings of insecurity, but are seen separately from the more classical, more urgent police concerns such as robbery and violence directed at people and property. More precisely, of the 11 quantified objectives laid down for the BTP by the BTP Authority, most are seen in terms of the clear-up rate for offences (Hamelin et al. 2007, pp. 52-57). Such use provides an instructive case of regeneration of a policy via instrumental innovation (Hamelin 2010). Thus it is readily understandable that this governance tool imposed by TfL poses real problems for the police: "Reporting takes us a lot of time, too much time, because the BTPA performance management system and the CompStat system are quite different?' (interview with two BTP constables; see also HMIC 2007). With the BTP management summoned to provide a weekly report around which a standardized "CompStat meeting" is organized, the combination of the two words "customer" and "governor" really means something. 
In another concrete expression of the BTP's problematic attentiveness to its many political authorities, for the last four years, in the County of Merseyside (Liverpool's county) the $\mathrm{BTP}^{5}$ has kindly agrred to program a part of its daily operations within the framework of a global "Merseyside TravelSafe policy". This local policy was co-designed by the local TOC MerseyRail and the local public transport authority MerseyTravel, which co-financed in 2005, with the aid and supervision of the Home Office, the recruitment of twenty PCSOs (police community support officers). With limited police powers, the PCSOs assist the BTP in the policing of the local rail network. Assistance from PCSOs, along with accreditation for some of them, has been made possible by the Police Reform Act of 2002, first for the Metropolitan Police Service, then for the other Home Office police forces and eventually for the BTP. These examples suggest a BTP which, despite its status as a national police force, has had to reorganize itself to fit with the specific characteristics of the regional and sub-regional segments of the rail network whose security it ensures (Thoenig 2006).

In addition, the staff of the BTP has been professionally configured to offer its partners interesting functions. First, its police officers are presented, and trained, as rail transport specialists. This means that in their daily and/or strategic activity they have developed a form of expertise reconciling, on one hand, a classical constabulary rationale (arresting, investigating, intercepting, reporting, interrogating, etc. within the established national legal police framework) with, on the other hand, the specific and/or local business approach of their clients. To cite one example, in cases involving parcel bomb alerts or deaths on the tracks, mostly suicides, the BTP has developed procedures combining regulation police handling of the situation with minimal times of train immobilization and station closing. The BTP's clients are, in order of their financial weight, Network Rail, TfL, interurban TOCs like Virgin, and regional TOCs like MerseyRail. They are unanimous in one respect: under no circumstances, on their networks and lines and in

\footnotetext{
${ }^{5}$ Of which the headquarters in Liverpool are in the same office building as the local TOC MerseyRail. Informal, improvised but useful meetings can start in the elevator!
} 
their stations, would they wish to see the BTP replaced by Scotland Yard or any of Great Britain's 42 Home Office county police forces.

The main causes of dissatisfaction among BTP partners are of two kinds. First, they see the BTP's core constabulary side, counterterrorism activity and crime clear-up, as too heavily emphasized, when they would prefer greater focus on deterrence, prevention and education as a means of promoting train use and diminishing such petty crimes as graffiti or vandalism. Even so, BTP chiefs have no hesitation about meeting specific expectations, even when these demand markedly unequal distribution of resources among units in different parts of the country. A good illustration is provided by the special facilities and financing enjoyed by the units in charge of the London Underground, under pressure from the British government and the capital's authorities. Just over a quarter of BTP personnel, some 900 people, work in Greater London. Also, in 2002 between July 26 and August 4, MerseyTravel and MerseyRail did not really appreciate but eventually had to accept that three quarters of the BTP agents usually based in Liverpool were mobilized to help police at the Commonwealth Games held in Manchester.

\section{Making the most of an opportunity structure favorable to the institutional status quo}

Unlike private TOCs, the local political authorities surrounding the BTP enjoy enough sovereignty to engage with it in power struggles which put into question its national status and hence its very organizational existence. This is obvious in the case of the London scene. Given the London BTP unit's numerical, financial and symbolic weight, the merger with the Metropolitan police service would amount, institutionally, to signing the organisation's death warrant. Maintaining the BTP's regional entities and thereby its unity would no longer make much sense. These entities would become easy prey for the county police forces of the country, some of which are numerically very substantial. In order to maintain its unity the BTP has employed various strategies (professional, compromise-oriented, institutional, opportunistic and 
symbolic) to cope with its threatening political environment and eventually pacifying and stabilizing it, always playing with the slack, the uncertainty and the divergences within the system.

\section{Putting professionalism forward}

Let's stay in London for a short while. From 2005 on, the BTP leadership, which is opposed to the merger with the MPS, has had enough solid arguments and convinced allies in Parliament to neutralize the determination of the preceding mayor of London, Ken Livingstone, and the then MPS Commissioner Sir Ian Blair to endow London with a unified police force. The main feature of their case is the possession of a specific set of skills, distinctive professional procedures and routines distinguishing BTP agents from the county polices. For instance, they are aware of the cost and other problems involved when a line or station is shut down by a death or a terrorist threat or is abnormally crowded (need for specific crowd management). BTP agents can also handle noisy supporters or hooligans in stations or trains. And they can successfully investigate thefts of cuprous metals in train depots where other police officers are indifferent to this type of crimes. During the first phase of our investigation in June 2006 we met the BTP officers managing the ad hoc "contingency planning team" set up to plan the very probable (according to them) and safe return from Germany by train of the football World Cup to victorious England. The operators seem convinced that while the county police would close the station for the duration of their investigation or apply the precautionary principle and evacuate the station in cases of danger, the BTP officers would carefully weigh up both the real risk passengers were running and the financial risk their decision imposes on the operators. Hence the operators appear objectively as the BTP's allies against a merger that threatens to water down their specific character as transport police. These allies include TfL, even though at the time of our investigation its chairman was Ken Livingston.

Of course, finding allies cannot be sufficient. The BTP also has to display and to claim good performance figures, this is rather important in an NPM context: «It has been stated by 
BTP that, on average, a closure of the railway put in place by the Metropolitan Police will have a duration 2.5 times that of a BTP imposed cloture » (AECOM 2011 : 30).

\section{Playing with diverging interests and shared governance}

The BTP has displayed an ability to deal with or satisfy numerous diverging interests. BTP clients find the body too costly in terms of their policing needs. In other words, they feel a change of ratio is called for: fewer BTP officers and more civilians and security agents with no constabulary powers. The BTP's institutional and professional strategy blunts this pressure for "discount" police work considerably. Rather than opposing it directly, the BTP has chosen the path of compromise: while firmly defending its personnel and its unique specialized expertise, the BTP gives a favorable reception to the TOCs' suggestions for adding security agents to patrols or having civilians man the control rooms for the various systems of camera surveillance in stations and trains. For example in Liverpool, MerseyRail has contracted with the Carlyle Group for thirty patrolling security agents, this contract amounting to fone million per year (by way of comparison, in MerseySide the BTP employs 20 PCSOs, 64 constables, 9 sergeants and three inspectors).

By providing these para-police groups with quick training and in some cases accreditation (for ACSOs, "accredited community support officer"), BTP chiefs offer their clients tokens of goodwill regarding their felt needs in the security field. The reinforcing of BTP numbers, both by security staff from the transport operating companies and PCSOs or ACSOs, is also much appreciated by local political representatives and user associations. Thus the BTP has successfully implemented the Home Office's more or less overt police reform strategy of 2002 (Blair 2002): it has become in the rail sector the pater familias of what the Home Office officially calls the "police extended family" (Johnston 2003). BTP clients set out to use para-police systems to contain BTP size and cost and to build up autonomous safety/security policies. However, practically, the result has been rather the opposite: the larger para-police numbers are, the more crimes and 
misdemeanours are detected and the more "necessary" it becomes to call on BTP agents. The fact that many of these para-policemen seriously envisage joining the BTP, partly for reasons of salary and work conditions, does of course strengthen the new centrality of the BTP within the $\mathrm{UK}$ rail security/safety system.

\section{The BTP ability to deal with new steering instruments}

There has been for decades in the United Kingdom a more or less overt conflict between the Home Office Police Forces and the few Non-Home Office Police Forces, of which the BTP is the largest. One option always examined by the successive BTP reviews bears on the question of whether, instead of being a separate force, the skills and services delivered by the BTP could be scattered into the 43 County Forces of Great-Britain. In this respect, the project of merging the London BTP unit with MPS must currently be considered the principal battlefield of this conflict. Responsible to the Ministry of Transport, the BTP is accorded special treatment, but its officer corps has continuously striven to achieve the same level of legitimacy and, by extension, of remuneration, training, mobility, etc. as Britain's other police forces and the MPS in particular. It has done this by doing its best to preserve and foreground its professional and organizational attributes, its partially "a-territorial" jurisdiction, for example, and via an organization, the British Transport Police Federation, that represents its specific interests. For many years the BTP's representatives have been fighting for salaries equivalent to those of police forces responsible to the Home Office. Thus the distinction between the two types of police force hinges on social and employment status, salaries, professional organizations and career management systems that are not completely equivalent. Implicit in the merger with the MPS, then, are issues relating to human resources management and administrative organization. There are also administrative overlaps between the MPS and the BTP, with respect to their anti-terrorist units, for instance (Dunmore 2006). As seen before, the merger would have repercussions for the English police system which, at the moment, remains favorable to the status quo. Even so, the document 
Modernising the British Transport Police, published in 2001, aims to give the BTP the same status as Home Office Police Forces in terms of salaries, responsibilities and powers. This attempt at rapprochement between the BTP and the Home Office Police Forces doubtless works less in favor of the move towards fusion than of retention of the status quo (ACPO 2008). Today, by standardization of management information and automation of data systems across all BTP Areas, BTP has been "brought in line with (...) the Home Office Forces and has delivered significant improvements in achieving Policing Plan Targets, placing BTP in a strong position relative to the 43 Home Forces, improving its effectiveness and increasing its credibility throughout the Rails Industry and the Policing Community" (AECOM 2011: 9). To sum up, this is a police force increasingly like other police forces, but one which for the moment the Ministry of Transport has no intention of letting go.

In order to institutionalize and pacify this odd and irritating status (it's like except that it's not) the department of Transport and the BTP successfully promoted, in the beginning of the 2000's, the creation of a specific and pluralist BTP Authority (BTPA) in the image of all the other Home Office police forces. Nevertheless, while swearing allegiance to the governance model of Home Office police forces, the BTPA also gave life to a formal transport security policy community reinforcing the BTP pivotal role in this field of public intervention. In other words, the BTPA embodies the message that the BTP does not officially belong to the state but to its publics, the TOCs and the rail passengers. The existence of the BTP thus strongly appears as a matter of public interest. However a careful examination of the BTPA composition and functioning shows that the private TOCs and their economic authority over the BTP cannot practically pilot the BTP's activity. In fact, without being represented in the BTPA the British government globally governs the BTP.

Created in July 2004, The BTPA institution was given responsibility for ensuring the effectiveness and efficiency of railway policing. As such, it establishes the BTP's budgets, monitors its activities and appoints both its Chief Constable and principal officers (Cf. part 3 of the "Railways and Transport Safety Act 2003, chapter 20"). Among the main measures taken by 
the BTPA since its creation is the ongoing augmentation of the BTP budget and this despite increasingly firm opposition from the operators who are the only BTPA members to actually finance the police.

One of the factors vital to understanding this paradox, the functioning of the BTPA and its role in maintaining the institutional status quo, lies in the composition of the BTPA. Among the 13 members of this autonomous body, the operators' representatives have a far from central position and find themselves in the minority on certain matters. The users' representatives, by contrast, seem to have a greater influence on controlling the BTP and setting it in motion. To some extent, the BTPA institutionalizes Sylvie Trosa's hypothesis that "Only organized pressure from users can bring public services up to standard in the services provided" (Trosa 1995, pp. 131).

Passengers have five representatives in the BTPA, of whom three represent the interests of passengers in Scotland, Wales and England. With them are more traditional actors in this kind of institution: the transport operators, NetworkRail included (5), the railways trade unions representative (1), and qualified individuals (2), of whom one is a police officer.

"(...) [D]oes that mean that, of all the funding operators, there will be only four representatives out of 13 or more?". This question, which downplays the fact that NetworkRail is not a normal operator, was asked by a parliamentarian ("Miss McIntosh") in the House of Commons on 11 February 2003, during a debate on the Railways and Transport Safety Act 2003 and the composition of the BTPA (United Kingdom Parliament 2003). For the operators, the possibility of finding themselves in the minority, inherent in the way representation was organized, was initially not a problem, security appearing to them only a marginal concern in the functioning of the railway system. But while at first there was disagreement among the operators, who were potentially in competition with each other, they are now unanimous in condemning the rising security costs that are squeezing their profits. Its composition, then, makes the BTPA disadvantageous to the private sector, the operators, and favorable to railway users and employees. Police Service 
Agreements" between BTPA and each TOC cover payment for 'core' policing services as "the fight against crime on the railway". The TOCs are allowed to negotiate additional resources with BTPA for "non-core" services, like "reassurance policing" or enhanced levels of core police services (DfT 2006). But these other services take place in other contracts between each TOC and the BTP. The contractual format imposed by the BTPA « sanctuarizes » the traditional BTP constabulary activity. To a certain extent this body, which directs the policing of crime in the railway system, can be seen as an able defender of the public interest against the private interests of the operators. On the one hand security is not mainly financed by taxes, and on the other it calls for a high level of spending. Some of the operators' representatives we met saw this instrument as "really two-faced", in the sense that it allows the government to officially "stay outside the game" and thus make few financial contributions.

\section{Playing with circumstantial opportunities and public legitimacy}

This paradoxical situation, privatization leading to an increased awareness of public security requirements, cannot be explained solely in terms of BTPA institutional design. Also involved is a specific set of circumstances. There can be no ignoring the arguments for improved security given the level of hooliganism on public transport, the very real threat of radical Islamic terrorism different from that of the IRA and the current rise in the theft of cuprous metals on the rail network. Responses have included extension of the BTP's powers beyond the rail system under Section 100 of the "Anti-terrorism, Crime and Security Act 2001" and in the "Police Reform Act 2002", which gave the BTP the right to enforce laws regarding antisocial behavior that previously required it to act in association with county police forces or, in cases involving the London Underground, with Scotland Yard (see also ACPO 2008). Thus the BTP has taken advantage of new threats to legitimize and restructure its activities. The 2004 Review of the BTP retains four main domains where the BTP has built up a valuable and unique expertise compared 
to the Home Office Forces: tackling 'route crime', counter-terrorism initiatives, major accident investigation and policing travelling football supporters (DfT 2004).

In addition to this extension of the BTP's legal powers and field of investment, we should not forget, either, the "contract" with the operators that provides no precise definition of the body's functions, together with, as already mentioned, the backing of a BTPA whose users' representatives have put the emphasis very much on rail network security. In the terrorism context alone the BTP has asked for and obtained financing for setting up an antiterrorist unit, for new infrastructure and adequate funding for the unit, and for the setting up of a dog squad now considered the largest in Europe. In 2004, the BTP review recognized that the BTP has a long established specialist capability in dealing with the terrorist threat to the network but often "supported the BTP's ambition to enhance its counterterrorism role" (DfT 2004). In London, the sharpness of the terrorist threat has become a resource for the BTP for at least two reasons. Firstly the media have focused the public's attention more on "real" security than on "felt" security. The BTP could therefore resist easily more to the felt-security policing orientation of TfL. Nevertheless, the terrorist risk also legitimizes the increased employment of PCSOs, under the BTP officers professional supervision, to improve the strategy of high visibility policing, judged efficient to deter terrorists from acting, and in fact to find a compromise with TOCs priority concerning reassurance policing. Second, the terrorist threat which became tragically real in 2005 in the London underground network gave the BTP all the necessary means to modernize its organization (e.g. creation of a paramilitary Special Weapons and Tactics, SWAT, unit) and its equipment (e.g. surveillance technologies) (Kraska et al. 2001). In terms of professional markers, the BTP has become a normal and up-to-date "generalist" police with nothing to envy to Scotland Yard, and this of course constitutes one extra argument against a hypothetical merger of the two police organizations. 


\section{Proudly standing for public interest}

Finally, or more exactly as a last resort, the BTP can mobilize the exclusive symbolic resources stemming from its public and national status more and more watertight each day. Those argumentative resources enable the BTP to contain the numerous authoritative moves of both the economic and local political authorities surrounding it. "The police service provides a public good. It is not a private security organization for a train operator $»$ pointed out a Chief Constable cited in the 2006 Review (page 13). The contract-based determination to meet the expectations of its main source of funding does not, however, generate an imbalance in the relationships between the managements of the BTP and TfL over private TOCs. While the commercial and financial mindsets of the operators seem excessively in contradiction with the demands of public safety, the BTP chiefs can still foreground their political authority in the light of their work in the general interest and the public status of their agents. This tension is illustrated by the following exchange:

Question: J.W. (Director of Transport Policing and Enforcement for TfL), who does P. C. (Chief Superintendent BTP of Area L) work for?

J.W.: P.C. works for the BTP, which is contracted to TfL to deliver transport policing services. Fundamentally, the BTP is there to deliver a policing service on our transport network. (...) Should the situation arise, which it has not, where either the BTP commanders said, W Well, actually, we are going to go our own way and do our own things', we would seriously question the value of the relationship and take steps to move elsewhere"(...).

I.J. (Chief Constable BTP): I see myself as working for (...) J.W. I do not see a conflict between [his] ambitions and mine. (...) The only potential for conflict there would be if the three million people who use the Underground system each day turned up outside my office and said we are going in the wrong direction. (...) We are still building a relationship (...) which will ultimately be founded around a concept of policing that is understood within the public good framework." (Excerpt from the proceedings of the first international executive session on transport policing, organized by TfL, 12 January 2006). 


\section{Conclusion}

Observed thirteen years after, the 1993 revolution which consisted in privatizing and dismantling British Rail has put the BTP on the track of radical transformation. The history of the BTP from WWII until now fits quite well with the "punctuated equilibrium" model of Romanelli and Tushman (1985, 1994). After a long period of stability, if not of slow decline (in the 1960's and 1970's the BTP ceased to police river transport, harbors and airports), the BTP entered, in 1994 (first agreements with the TOCs), into a phase of intense and wide-ranging adaptation. In 2004, with the installation of the BTPA, the BTP began again to function on stable and legitimate routines, so much so that it could resist the assaults of Scotland Yard and that the BTP topmanagement now dreams of recapturing the policing of British international airports.

During this 1994-2004 decade, the transformation of the BTP was far-reaching, for it touched all the components of the organization (Greenwood et Hinings 1996): its personnel with the massive recruitment of civilians, the nature of its activity which has been more clearly targeted and explicated from the bottom to the top of the hierarchy, its territorial structure, its performance management and, last but not least, its governance.

One can first link this tour de force, undergoing ample adaptation while remaining the BTP, to what happened within the organization during the strange lapse of four months between the promulgation of the 1993 Railways Act and that of the 1994 "Transport Police (Jurisdiction) Act". In this short interval the BTP was placed in a sort of legal and political no man's land, on borrowed time. The BTP's agents then feared the worst for their organization because the hypothesis of being thrown back to the pre-war configuration, each "train operating company" (TOC) having and running its own police, was technically and politically plausible. But instead of resigning themselves to what could appear to be an unavoidable fate, they put into motion processes of collective cognition and deliberation (Weick 1969; Bartunek \& Moch 1987) opening 
onto a strategy of resilience (Stewart and O'Donnell, 2007) which derived from a simple interpretation of the New Public Management national policy and "ambiance" of the time: "we have clients (the TOCs), let's deal and arrange with them".

Obviously the implementation of this strategy was at once more complicated and harsher than the strategy itself. Even though the NPM policy and ambiance legitimized strong pressure from the diverse clients for more accountability on the part of the BTP, the organization never adopted a posture of submission. The grim reality is that all the agreements, either local or national, bearing either on staff number or on performance management, etc., have been fiercely negotiated. As a player in this tough multi-level governance game, the BTP appeared quite imaginative. It hardened and put forward its unique professionalism, turned in its favor the "extended police family" policy, took advantage of the diverging interests of its partners, and cleverly seized the "terrorism opportunity" to recall its public interest essence.

Of course, the BTP is not a collective being with clear and rational intentions. It should rather be apprehended as an organization within which sufficient consent existed to attempt to remain united, state-wide and public whatever happened. Thus, one can ask the following "uchronical" question: if the BTP had not been momentarily forgotten in the Railways reform of 1993 would its chiefs and staff have shown so much organizational mindfulness and agility?

Our last conclusive remark will be a reminder of the relevance of intertwining public policy research and organizational studies (Bozeman 2011). Understanding how the BTP evolved over time implies comprehending the various sorts of interactions the BTP has with its multiorganizational environment. However, in order to have the full picture, one must contextualize and use public policy framework, because public policies condition or at least expresses the sense of intra- and inter-organizational practices. In the present case study at least three policy domains were involved: environment (favoring rail transport), transport and security. If one takes this last domain as an illustration, the significance of the advent of the BTP Authority can only be analyzed through a study of the Home Office general security policy. This policy aims to 
institutionally reassure county governments in terms of policing autonomy (creation of local police authorities) while letting the powerful and national Association of Chief police Officers (ACPO) discretely managing police activity state-wide through uniform recruitment procedures, professional training, constabulary practices guidelines, etc. It is a sort of "steering at a distance" (Kickert 1995). Putting into place a "Police Authority" signifies compliance to a policy standard and style conditioning the behavior of the Department of transport and the BTP. But it is also an expression of this behavior because it facilitates the understanding of why and how these two organizations have appropriated this "police authority" formula of "remote but firm-handed government" as a relevant solution to their own specific problems of governance.

Nevertheless the reverse is true too: organizational studies can notably inject a good dose of realism within policy research that is sometimes too ethereal. It is particularly the case here concerning this quasi-universal public management reform policy called New Public Management. Our study shows that the doctrinal puzzle image stuck on NPM by Christopher Hood (1991) is rather exaggerated. Real organizations in real policy contexts justly interpret NPM as a simple doctrine pleading for the introduction of market mechanisms within public service delivery for efficiency reasons. Furthermore, they do not confuse, on the first hand, the rampant spread of NPM uses in their policy domains with a totally new and implacable economic theory-driven regime that throws away all the values and practices of the past in order to replace them with competitive enterprise governance everywhere and at every level. Does the British rail system now resemble a "planned economy"? Yes, pretty much! Do the TOCs behave as normal customers, always right, when dealing with the BTP? This answer is "more or less". Has the BTP lost its professional monopoly on rail security matters? Not really. Is it at least subject to some kind of competition from private security agents recruited by the TOCs? Not at all; these agents practically reinforce the BTP.

From 1993 until now "the visible hand of the state" (Le Gales, Scott 2008) has put into controlled motion the invisible hand of the market with as a paradoxical result the reinforcement 
of the BTP publicness. Progressively New Public Management has yielded power to New

Publicness Management so that "Everything changes so that nothing changes" (Tomasi di Lampedusa 1958).

\section{References}

ACPO (association of Chief Police Officers of England, Wales and Northern Ireland) (2008), Coordinated policing protocol between the British transport police and Home Office police forces, memorandum $14 \mathrm{pp}$.

AECOM (2011), Rail Value for Money Study: British Transport Police Review, Report Commissioned by the DfT and the Office of Rail regulation (ORR),February 2011, 31 p.

ANDERSON S. (2012), "Public, private, neither, both? Publicness theory and the analysis of healthcare organisations", Social Science and Medicine, 74, 313-322.

APPLEBY, P. (1995), A force on the move: the story of the British Transport Police, 1825-1995, Worcestershire. Malvern Wells.

AYLING, J., SHEARING Cl. (2008), “Taking care of business: Public police as commercial security vendors", Criminology and Criminal Justice, vol: 8 (1), pp. 27-50.

BAILEY, D., SHEARING Cl. D. (1996), "The Future of Policing", Law and Society Review, 30/3, pp. 585-606.

BAILEY, D., SHEARING Cl. D. (2001), The New Structure of Policing: Description, Conceptualization and Research Agenda, Washington D.C., US Department of Justice, National Institute of Justice; July.

BARZELAY, M. (2001), The New Public Management: Improving Research and Policy Dialogue, Berkeley, University of California Press. 
BARZELAY, M., GALLEGO R.., (2006), 'From 'New Institutionalism' to 'Institutional Processualism': Advancing Knowledge about Public Management Policy Change’, Governance, 19(4), 531-57.

BARTUNEK, J.M., MOCH, M.K. 1987, "First-order, second-order, and third-order change and organization development interventions: a cognitive approach", The Journal of Applied Behavioural Science, 23(4), 483-500.

BLAIR, I. (2002). "Patrol Partnership, Police Review", 110, 30-31.

BOZEMAN, B. (2013), "What Organization Theorists and Public Policy Researchers Can Learn from One Another: Publicness Theory as a Case-in-Point”, Organization Studies, 34(2), 169-188.

BOZEMAN, B. (1987), All organizations are public: Bridging public and private organizational theories, San Francisco:Jossy-Bass.

BOZEMAN, B., BRETSCHNEIDER S. (1994), "The "Publicness Puzzle" in Organization Theory: A Test of Alternative Explanations of Differences between Public and Private Organizations' Journal of Public Administration Research and Theory: 4(2), 197-223.

BOZEMAN, B. (2009), "Public values theory: three big questions", International Journal of Public Policy, vol.4 (5), January, 369 - 375

DEPARTEMENT FOR TRANSPORT (2002 and 2007), Great Britain Transport Statistics Bulletin DEPARTEMENT FOR TRANSPORT (2004), Review of the British Transport Police, September, London.

DEPARTEMENT FOR TRANSPORT (2006), Review of the British Transport Police: Refocusing BTP, June, London.

DUDLEY, G. (1994), 'The Next Step agencies, political salience and the arm's-length principle: Barbara Castle at the Ministry of Transport 1965-68', Public Administration, 72(2), 219-40.

DUNMORE, G. (2006). 'Protecting Passenger Transport Systems from the Threat of Terrorism', Public Transport International, 1, 8-11. 
DUPONT B. (2006). "La sécurité intérieure au XXIe siècle: l'émergence des réseaux" in P. ZENRUFFINEN (sld.), Mélanges dédiés au professeur Bolle, Helbing \& Lichtenhahn, Neuchâtel, 2006, $347-358$

EDELMAN M. (1964), The Symbolic Uses of Politics, Urbana (Ill. USA), University of Illinois Press.

ERICSON R.V., HAGGERTY K.D. (1997), Policing the Risk Society, Toronto, University of Toronto Press.

FERRET, J., SPENLEHAUER V. (2009), 'Does "Policing the Risk Society" Hold the Road Risk', British Journal of Criminology, 49:2, March, 150-64.

FREEMAN, R., J. SHAW. (2000), All Change: British Rail Privatisation, London, McGraw-Hill.

GILL A. \& MAMODE Ph. (TFL) (2006). "Safer 'Transport for London' through mapping, analysis and partnership", Slides presented at the 4th National Crime Mapping Conference 24th - 25th May 2006, London.

GOUJON, S. (2004), "La réforme du secteur ferroviaire en Grande-Bretagne", Notes de synthèse du SES, DAEI, Ministère de l'Equipement (France), juillet-août, no. 154, 29-38

GOURVISH, T. R., ANSON M. J. (2002), British Rail, 1974-1997: from integration to privatisation, Oxford, Oxford University Press.

GRABOSKY, P. (2007). "Private Sponsorship of Public Policing", Police Practice and Research, Volume 8, Number 1, March 2007, 5-16.

GREENWOOD, R., HININGS, C.R. 1996, "Understanding radical organizational change: Bringing together the old and new institutionalism", Academy of Management Review, 21(4), 1022-1054.

HALL, P., TAYLOR, R. (1996), 'Political Science and the Three Institutionalisms', Political Studies, 44, 936-57.

HAMELIN, F. (2010), "Renewal of Public Policy via Instrumental Innovation, The Implementation of an Automated Speed Enforcement System in France", Governance: An 
International Journal of Policy, Administration and Institution, 23-3 (july), 509-530.

HAMELIN, F. (ed.), J. AUST, A. PURENNE and V. SPENLEHAUER. (2007). La police des chemins de fer. Leçons d'une analyse comparée France/Angleterre. Final report on the research commissioned from INRETS by INHES, September, 165 pp.

HER MAJESTY'S INSPECTORATE CONSTABULARY (2007), The British Transport Police, London, UK Home Office Inspection Report (November).

HOOD, C. (1983), Tools of Government, London, MacMillan

HOOD, C. (1991), “A Public Management for all Seasons?”, Public Administration, 69, pp. 3-19.

JONES, T., T. NEWBURN. 2002, "The transformation of Policing? Understanding Current Trends in Policing Systems", British Journal of Criminology, 42, 129-46.

JOHNSTON, L. (1992), The Rebirth of Private Policing, New York, Routledge.

JOHNSTON, L. (2003). "From pluralisation to the police extended family: discourses on the governance of community policing in Britain", International Journal of the Sociology of law, vol. 313, 185-204.

JOHNSTON, L., SHEARING Cl.D. (2003), Governing Security, Explorations in Policing and Justice. London. Routledge.

KICKERT W., (1995), « Steering at a distance: a new paradigm of public governance in Dutch higher education », Governance, 8 (1).

KRASKA, P.B., ed. (2001), Militarizing the american criminal justice system: the changing roles of the Armed Forces and the police, Boston, Northeastern University Press.

LE GALES, P., A. SCOTT. (2008), “Une révolution bureaucratique britannique ? Autonomie sans contrôle ou "freer markets, more rules"”, Revue française de sociologie, 49(2), 301-330.

LODGE, M. (2002). On different tracks: designing railway regulation in Britain and Germany, Wesport/London, Praeger.

MINTZBERG H. (1979), The Structuring of Organizations, Englewood cliffs, Prentice-Hall. 
MOUlTON, S. (2009), "Putting Together the Publicness Puzzle: A Framework for Realized Publicness", PAR, 69(5), 889-900.

PESCH, U. (2005), The Predicaments of Publicness: An Inquiry into the Conceptual Ambiguity of Public Administration, Delft (NL), Eburon.

PRESSMANN, J. L., WILDAVSKY A. (1973). Implementation: How Great Expectations in Washington $D C$ are dashed in Oakland, Berkeley (CA), University of California Press.

ROMANELLI, E., TUSHMAN, M.L. (1994), "Organizational transformation as punctuated equilibrium: An empirical test", Academy of Management Journal, 37(5), 1141-1166.

STEWART, J., O'DONNELL, M., (2007) "Implementing change in a public agency: Leadership, learning and organisational resilience", International Journal of Public Sector Management, Vol. 20 (3), pp.239-251

THOENIG, J.-Cl. (2006). "Modernizing Sub-National Government in France: Institutional Creativity and Systemic Stability", in HOFFMANN-MARTINOT V., WOLLMANN H. 2006. State and Local Government Reforms in France and Germany, Divergence and Convergence, VS Verlag für Sozialwissenschaften, 39-58.

THOENIG, J.-Cl. and DUPUY F. (1979), "Public Transportation policy-making in France as an implementation problem", Policy Science 11/1:1-18.

TROSA, S. (1995), Moderniser l'administration: comment font les autres?, Paris, Editions d'Organisation.

TUSHMAN, M., ROMANELLI, E. (1985), "Organizational evolution: A metamorphosis model of convergence and reorientation", Research on Organizational Behavior, 38, 1-23.

UNITED KINGDOM PARLIAMENT (2003), Standing Committee on Bills, Railways and Transport Safety Bill, 11 February (column 170) (http://www.publications.parliament.thestationery-office.com/)

WEICK K.E. (2001), Making Sense of the Organization, Blackwell 
ZHONG, L., GRABOSKY, P. (2009), "The Pluralization of policing and the rise of private policing in China", in Crime, Law and Social Change, Nov., vol. 52, issue 5, 433-55. 